\title{
LEGAL PROTECTION ON THE INTELLECTUAL PROPERTY LOCAL LEADING PRODUCTS ON IMPORTED PRODUCTS ERA OF THE ASEAN ECONOMIC COMMUNITY IN PALEMBANG CITY
}

\author{
Nina Yolanda, SH., MH. \\ Lecturer University of Palembang \\ DOI: 10.31364/SCIRJ/v7.i4.2019.P0419637 \\ http://dx.doi.org/10.31364/SCIRJ/v7.i4.2019.P0419637
}

\begin{abstract}
:
One of the existence of the Asean Economic Community is to bring consequences to the opening of trade in goods and or services easily throughout Southeast Asia, which also influences the competition of local superior products against foreign imported products in Palembang City. Intellectual property-based legal protection of local superior products can have an impact on economic value for the welfare of business actors in regions, especially Micro, Small and Medium Enterprises so that they can compete healthily with imported products from abroad.

This Research aims: 1. To analyze the intellectual property-based legal protection of local superior products on imported products in the era of the Asean Economic Community in Palembang City; 2. To provide solutions regarding the efforts of the regional government of Palembang City in providing intellectual property-based legal protection to local superior products.

This research is normative legal research, using primary legal materials, secondary legal materials with tertiary legal materials and analysis using qualitative deductive methods.

The results of the research show: 1. Intellectual property-based legal protection has basically been accommodated in legislation in Indonesia, but in the city of Palembang, the Micro, Small and Medium Enterprises have not fully understood the importance of intellectual property protection, resulting in minimal registration; 2. Local governments have programs that continuously disseminate industry and trade by utilizing intellectual property-based laws and technology so as to encourage businesses to be competitive with imported products that enter the city of Palembang.
\end{abstract}

Keywords: Legal Protection, Intellectual Property, Local superior products, Import products, Asian Economic Community.

\section{A. INTRODUCTION}

The Intellectual Property Regime is an increasingly interesting issue to study because of its increasingly decisive role in accelerating the pace of national development, especially in the era of globalization. In this connection the era of globalization can be analyzed from two dominant characteristics. First, the era of globalization is marked by the widespread opening of relations between nations and between countries supported by transparency in information. Second, the era of globalization opens up opportunities for all nations and countries in the world to be able to know their potential. abilities and needs of each.

Intellectual property also spread to all areas of people's lives. Although intellectual property is a right (private rights), in turn intellectual property enters the economic arena. Intellectual property rights serve and contribute to the business world, one of which deals with the Micro, Small and Medium Enterprises group. The Potential and Role of Micro, Small and Medium 
Enterprises, a sector that has not been dealt with seriously, but has been able to become the backbone of the nation's economy from the crisis to the present. The Micro, Small and Medium Enterprises sector has acted as an economic safety net and the social safety net is capable of absorbing large numbers of workers so as to reduce national unemployment, help alleviate poverty and make a significant contribution to Gross Domestic Product.

\section{B. LITERATURE REVIEW}

\section{Intellectual Property}

The term intellectual property linguistically, the term property when it first appeared in 1787 has a meaning that includes all things that can be put value and rights easily by services throughout Southeast Asia so that it also influences the competition of local superior products against foreign imported products in Palembang City . Intellectual property-based legal protection of local superior products can have an impact on economic value for the welfare of business actors in regions, especially Micro, Small and Medium Enterprises so that they can compete healthily with imported products from abroad.

The existence of Intellectual Property originates from concepts derived from natural law that have contributed to the law in the modern era. The conventions in Intellectual Property Rights state that this field is part of the theory of natural law which is popular in Continental Europe that intellectual property is not created by law, but because it does exist.

The empirical results provide evidence that intellectual property rights contribute to positive and significant economic growth in the case of a full sample of countries. Furthermore, by classifying all sample countries into countries with high middleincome, middle-low income countries and low-income countries, we have found that the impact is more in high-income countries than in middle-income countries and low. In addition, it also concludes that the impact of intellectual property rights on economic growth is more effective in middle and upper countries compared to those in lower middle income countries, which in turn is stronger compared to low-income countries.

Indonesia, to regulate trade agreements and economic agreements as developments, a global culture that allows many imitations of products of human creativity, then developed arrangements regarding intellectual property as a guarantee in international trade. This is indicated by the establishment of the World Trade Organization (WTO) in 1994 which included the Agreement on Trade Related Aspects of Intellectual Rights.

\section{ASEAN Economic Community}

in 2015 it was a year of determination for the Indonesian economy, especially with the beginning of the effective functioning of the Asian Economic Community: Indonesia would become a warrior, or otherwise a loser in the region. One of the most extensive, ambitious, and in front of the eye is the ASEAN Economic Community, one of which is the formation of the ASEAN single market in 2015. In ASEAN itself a bilateral free trade agreement was taken because the progress of AFTA was considered too slow. The Asian Economic Community which will make ASEAN a single market and competitive production base in the region, also forms from ASEAN's response to the rise of the Chinese and Indian economies, as a single market, all trade barriers both tariffs and tariffs,

abolished. Anticipation, especially we must do related to the liberalization of the service sector as a sensitive sector. Five service sectors agreed to be liberalized are health services, tourism, e-commerce, air transportation, and logistics. All five in 2015 will be free to trade across countries. Service trade regulates the liberalization of professional labor and manufacturing workers. For professionals there are five categories that are agreed to start operating freely in 2015, namely nurses, doctors, dentists, accountants, and engineers.

Professional workers and laborers who cross this country must meet the standards set in ASEAN. 


\section{RESEARCH METHODS}

1. Type and Research Approach

This research is a descriptive normative juridical approach. This study will try to describe and explore the aspects of dassalient / norms that exist in regulations relating to intellectual property and other legislation. This research is based on document, aspecially secondary data. Which is relevant to the problem, then to complete the field data, a study will be conducted from the empirical aspect, namely the reality in the field.

\section{Data Types and Data Collection Techniques}

The type of data collected includes secondary data and primary data. Primary data obtained through unstructured interviews by means of two-party interaction does not rely on interview guides (guide interviews) which contain questions that are not bound to a particular form. As secondary data, legal materials are used in the form of primary legal materials, secondary legal materials and tertiary materials.

\section{Data Collection, Processing and Analysis}

Legal data obtained in the study will be inventoried, classified, described. connected and analyzed. In order to answer the problems that have been described and then processed deductively, namely drawing conclusions from something. In the process of analyzing secondary data, researcher stricktly only collect relevant data.

\section{RESULTS AND DISCUSSION}

1. Legal protection of intellectual property of local superior products for imported products in the era of the Asian Economic Community in Palembang City.

Palembang city.have a variety of products produced by Micro, Small and Medium Enterprises. At present there are 10,000 units of small and medium enterprises in Palembang with various types of businesses. The Department of Industry and Trade of Palembang City develops products that are general in nature to the concrete problems faced next in collecting, managing and analyzing materials taken by qualitative analysis.

Leading faces the free market of the ASEAN economic community or the Asian Economic Community 2015. Related to the issue of globalization in the national economy, making Micro, Small and Medium Enterprises need to be managed in a global context. The rapid import of consumer goods has made an increase in domestic industry competition. On the other hand, the difficulties of national products entering foreign markets also illustrate the tight competition in overseas industries. This is where the big problem is for Indonesia's Micro, Small and Medium Enterprises. Demands for democratization come together with demands for increased competitiveness. The market has not yet been formed but competition must be carried out. Micro, Small and Medium Enterprises must compete with business people from all corners of the world. As an anticipatory step towards the collapse of the dominance of domestic products in the national trade arena, product quality standardization must be carried out, especially for Small and Medium Enterprises to be able to compete in the free market, especially in the era of the Asian Economic Community.

The large number of Micro, Small and Medium Enterprises in Palembang City is a separate asset that will strengthen the foundation of the regional economy, and can be a source of income for the Regional Government. In addition, peransert Micro, Small and Medium Enterprises can realize economic growth, equity and increase in community income, job creation, and poverty 
alleviation. The Palembang City Integrated Business Service Center has seven Companion Consultants who have the responsibility of assisting Micro, Small and Medium Enterprises spread in the City in Palembang City. One of the assisted concentrations is Micro, Small and Medium Enterprises which have superior regional potential products. Thing

This aims to elevate the superior products of the local area to be more widely known by the community. This activity was carried out in line with the Palembang City Cooperative and Micro, Small and Medium Enterprises Service program and the Vision of the Integrated Business Service Center of Palembang City in order to develop regional superior potential through coordination with the Micro, Small and Medium Enterprises Cooperatives as soon as possible. The forms of activities are to provide assistance, and empowerment of Micro, Small and Medium Enterprises in a comprehensive, optimal and sustainable manner through the development of a conducive business climate, providing opportunities for business, support, protection and business development to the greatest extent so as to increase their own position, role and business potential .

2. The efforts of the regional government of Palembang in providing intellectual property-based legal protection to local superior products

Palembang City Government must increase the promotion of products through exhibitions or working with stakeholders, especially the tourism sector, Palembang's Micro, Small and Medium Business Products are not less competitive with products from other regions and abroad. However, these products are not well promoted. Can be done to carry out the promotion of these products. One of them is through participating in various events / exhibitions, then especially the Indonesian Palembang Hotels and Restaurants Entrepreneurs who also promote the products, for example Indonesian Entrepreneurs and Hotels can display these products in their hotels or for food, hotels

and restaurants in Palembang can serve these foods in one food menu. In addition, the various products to be immediately registered intellectual property, namely in the form of copyright, patents, brands and industrial designs. Thus, the existence of superior products based on Intellectual Property is not claimed by other parties, so that the product is well-known as someone else's product, even though it is evident that the product belongs to the people of Palembang.

The regional government has a program that continuously promotes industry and trade socialization by utilizing intellectual property-based laws and technology to encourage business actors.

\section{E. CLOSING}

Based on the results of the research, it can be concluded as follows:

1. Intellectual property-based legal protection has basically been accommodated in legislation in Indonesia, but in Palembang City, the Micro, Small and Medium Enterprises have not fully understood the importance of intellectual property protection so that registration is still minimal;

2. Regional Governments have programs that continuously disseminate industry and trade by utilizing laws and technology based on intellectual property so as to encourage businesses to be competitive with imported products entering the city of Palembang.

3. The results of this study are expected to be the material for the next research and discussion process.

\section{Bibliography}

1. Zen Umar Pubra, "Sistem Hak Kekayaan Intelektual dan kaitannya dengan UKM" makalah, disampaikan pada acara Peresmian SME Center dan Panel Diskusi, Jakarta, 7 November 2001.

2. Jill McKeought, Kathy Bowreydan Philip Criffth, 2002, Intelectual Property, LawBook Co, Autralia. 
3. Michael W. McConnell, 2010, "Natural Rights and the ninth Amandment : How does Lockean Legal Theory Assist in Interpretation?" Journal of Law \& Liberty, Volume 5, No. 1, New York University.

4. Prasetyo Nugroho, 2014, "Membangun Sistem Perlindungan Hak Kekayaan Intelektual di Indonesia".Journal BPSDM Hukum dan HAM, Vol. I, No. 1, Jakarta, Kementerian Hukum dan HAM.

5. Syprianus Aristeus, "PELUANG INDUSTRI DAN PERDAGANGAN INDONESIA DALAM PELAKSANAAN MASYARAKAT EKONOMI ASEAN (Industry and Trade Opportunity of Indonesia on Asean Economic". Jurnal Rechtsvinding, Volume3 Nomor 2 Agustus 2014.

6. Robert T. Holt and John E. Turner (ed), “The Methodology of Comparative Research”, The McMillan Company (1970).

7. Sugiyono, "Metode Penelitian Kombinasi (Mixed Methods)", Alphabeta, 2013. 